\title{
Microbiology of shallow subsurface aquifer and carbonate rocks studied by culture-dependent and culture-independent methods. Preliminary results on an underground laboratory, the LSBB, Rustrel, France
}

\author{
Grégoire Galès ${ }^{1,2, a}$, Gaël Erauso ${ }^{2}$, Jean-Luc Cayol ${ }^{2}$, David Navarro ${ }^{3}$, Daniel Boyer ${ }^{4}$, \\ and Gilles Micolau ${ }^{5}$ \\ ${ }^{1}$ Aix-Marseille Université, CEREGE, Centre St Charles, Case 67, 3 place Victor Hugo, \\ 13331 Marseille, France \\ ${ }^{2}$ Aix-Marseille Université, Université du Sud Toulon-Var, CNRS/INSU, IRD, MIO, UM 110, \\ 13288 Marseille Cedex 09, France \\ ${ }^{3}$ INRA, UMR 1163 Biodiversité et Biotechnologie Fongiques, Marseille, France \\ ${ }^{4}$ LSBB, University of Nice, University of Avignon, CNRS, Aix-Marseille University, \\ La grande combe, 84000 Rustrel, France \\ ${ }^{5}$ UMR EMMAH Environnement Méditerranéen et Modélisation des Agro-Hydrosystèmes, \\ INRA/Université d'Avignon et des Pays de Vaucluse, 33 rue Louis Pasteur, 84000 Avignon, France
}

\begin{abstract}
We investigated the microbiology of a shallow subsurface site, the LSBB, located near Avignon. This site lies in carbonate rocks, belonging to the Urgonian facies. Rock, concrete and water samples were collected and directly transferred to the laboratory. Studies of microorganisms as pure cultures are the only way to get their real physiological properties. Nevertheless, microbiologists cannot cultivate and isolate the majority of microorganisms for several reasons, one being our lack of understanding of their minimal needs. Molecular studies, e.g. extraction and sequencing of the total nucleic acids present in an environment provide phylogenetic and metabolic information on uncultivated microorganisms. We performed aerobic and anaerobic culture with various electron acceptors and donors, searching for heterotrophic, methanogenic, sulphate- nitrate- and FeIIIreducing Prokaryotes. We also performed DNA extractions and PCR amplification of ribosomal RNA genes, to test if our protocols were adapted to this environment. Our results show that the LSBB galleries are colonized by a low diversity microbiote, with a strong influence of anthropogenic activities. Further studies will link the microorganisms biodiversity and the petrophysic properties of rocks.
\end{abstract}

\section{Introduction}

It became apparent during the last decades that life could occur deeper than previously presumed in the underground or subsurface [1]. Several deep habitats, including geothermal springs, oceanic crust, gold mines, oil reservoirs... were colonized by a large diversity of Prokaryotes (microorganisms which live without a cell nucleus, e.g. Archaea and Bacteria).

\footnotetext{
${ }^{\text {a }}$ Corresponding author: gregoire.gales@univ-amu.fr
} 


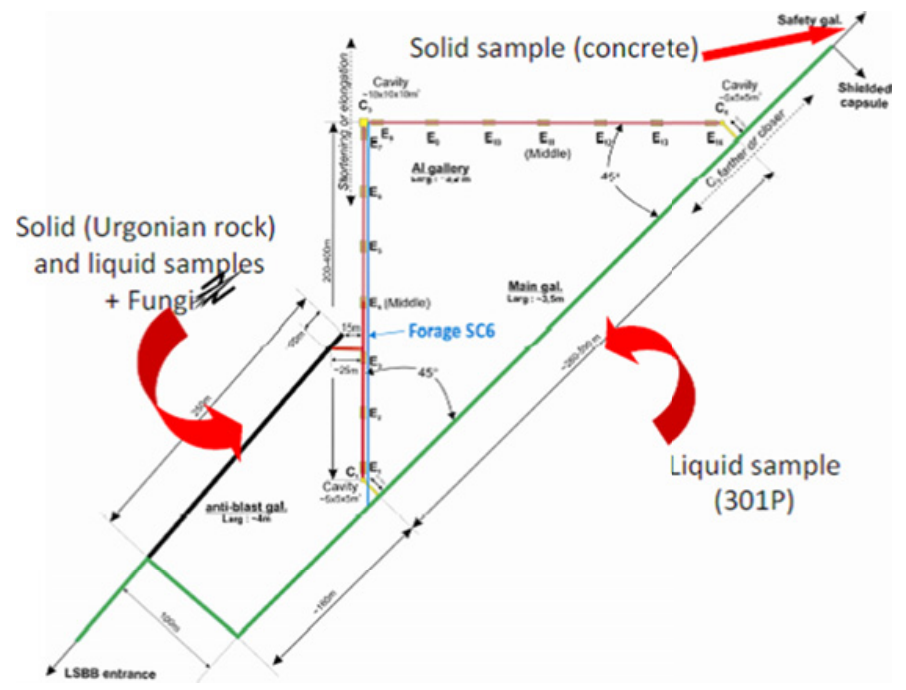

Figure 1. Localization of the sampling area.

Carbon sequestration in subsurface could be one of the ways to reduce the effect of anthropogenic carbon dioxide emissions. Bacterial-induced carbonate precipitation allows the filling of fracture and the optimization of injected quantities, thus being a concern on safety and efficiency [2]. To understand if indigenous subsurface microflora could affect carbon dioxide sequestration, we studied the microbiology of a shallow subsurface site, the LSBB, located near Avignon. This site lies in carbonate rocks, belonging to the Urgonian facies. We present here some preliminary results.

\section{Material and methods}

\subsection{Sampling}

Drilling deep geological formations through hundred meters generates costs higher than further microbiological analyses. Many subsurface studies benefit from windows open into earth crust, like mines and drillings for oil-producing wells. But drilling and building oilor water-wells have considerable impact on the ecosystems. Inside the well tubing, physicochemical conditions are far from those prevailing in subsurface and microbial biofilm adhere to the well pipes. Therefore, microbial communities sampled from oil- and water-wells do not obligately reflect their subsurface counterpart.

We chose to sample rock, concrete, biological (a Fungi) and water samples. Samples location is indicated on Fig. 1. These samples were directly transferred to the laboratory for further characterization.

\subsection{DNA extractions and PCR}

Rock samples were crushed in a mortar under anaerobic and sterile conditions. Crushed rock samples $(0.3 \mathrm{~g})$ or water $(500 \mu \mathrm{l})$ or harvested cells from pure cultures $(500 \mu \mathrm{l})$ were suspended in $1 \mathrm{~mL}$ TE-Na-1X lysis buffer $(100 \mathrm{mM}$ Tris, $50 \mathrm{mM}$ EDTA, $100 \mathrm{mM} \mathrm{NaCl}$, $1 \%$ SDS (w/v), $1 \%$ (w/v) Sarkosyl, $\mathrm{pH}$ 8.0). Cells were disrupted by bead beating using 
Lysing Matrix E (MP, Biomedicals). After digestion with proteinase $\mathrm{K}\left(1 \mathrm{mg} \cdot \mathrm{ml}^{-1}\right.$ final) for $1 \mathrm{~h}$ at $55^{\circ} \mathrm{C}$, DNA was extracted twice with a volume of phenol/chloroform/isoamyl alcohol (25/24/1; $\mathrm{pH} 8.0)$, then with a volume of chloroform. Aqueous and organic phases were separated by centrifugation at $13,000 \mathrm{~g}$ for $15 \mathrm{~min}$ at $4^{\circ} \mathrm{C}$. DNA was precipitated with 0.7 volume of isopropanol, pelleted by centrifugation at maximum speed for $15 \mathrm{~min}$, then air-dried and finally resuspended in $30 \mu \mathrm{L}$ of TE $1 \mathrm{X}(10 \mathrm{mM}$ Tris,. $\mathrm{HCl}, 2 \mathrm{mM}$ EDTA, pH 8.0).

The 16S rRNA gene was amplified by PCR using the universal primers Rd1 (5'-AAGCGGTTGCCGCCGACCGACC-3') and Fd1 (5'-AGAGTTTGATCCTGGCTCAG$3^{\prime}$ '). $16 \mathrm{~S}$ amplicons were then stored at $-80^{\circ} \mathrm{C}$ before analyses (work in progress). The Fungi was studied by the amplification of the ITS6 region.

\subsection{Culture of microorganisms}

A basal medium was defined, containing $\left(1^{-1}\right): 2 \mathrm{~g} \mathrm{NaCl}, 0,5 \mathrm{~g} \mathrm{~K} \mathrm{HPO}_{4}, 0,5 \mathrm{~g} \mathrm{KH}_{2} \mathrm{PO}_{4}$ and $0,5 \mathrm{~g}$ yeast extract. The $\mathrm{pH}$ was adjusted to 8.5 (corresponding to the $\mathrm{pH}$ measured from the rocks and water samples) with $10 \mathrm{M} \mathrm{KOH}$. To target some physiological prokaryotic groups, we made aerobic (targeting aerobic microorganisms) and anaerobic cultures. To obtain anaerobiosis, the medium was boiled under a stream of $\mathrm{O}_{2}$-free $\mathrm{N}_{2}$ gas and cooled at room temperature. Aliquots of $5 \mathrm{ml}$ were dispensed into Hungate tubes, degassed under $\mathrm{N}_{2} / \mathrm{CO}_{2}(80: 20$, v/v) and subsequently sterilized by autoclaving at $120^{\circ} \mathrm{C}$ for $20 \mathrm{~min}$. After autoclaving, the gas phase was changed for a $\mathrm{H}_{2} / \mathrm{CO}_{2}$ ( $80: 20$, $\mathrm{v} / \mathrm{v}) \mathrm{mix}$. In anaerobic cultures, we provided when needed nitrate and succinate $(10 \mathrm{mM}$ each, targeting nitrate-reducing microorganisms $), \mathrm{FeCl}_{3}$ and citrate $(10 \mathrm{mM}$ each, targeting Iron-reducing microorganisms), lactate and sulphate $(10 \mathrm{mM}$ each, targeting sulphatereducing microorganisms) and methanol and formiate $(10 \mathrm{mM}$ each, targeting methanogenic Archaea). After microscopic observations of liquid cultures, we inoculated solid media (Petri dishes or Roll-tubes) to obtain pure colonies. Cultures were performed at ambient temperature.

DNA from pure colonies was extracted as explained before, 16S rRNA gene was also amplified and sequenced. 16S rRNA genes of pure cultures were determined and analyzed using the RDP database [3, 4]. The sequences were compared with available sequences in GenBank, using a BLAST search. For a sequence showing only $97 \%$ similarity with that of Pectobacterium aroidearum, we built a phylogenetic tree whose topology was determined using the neighbour-joining method (Fig. 2). Support for internal nodes was assessed by bootstrap analysis (1500 replicates) [5]. These analyses were conducted in MEGA6 [6].

\section{Results}

\subsection{DNA extractions and PCR}

Among the factors that limit the ability to extract nucleic acids from carbonate reservoirs is the low number of bacterial cells generally associated with nutrient depleted environments and the chemical nature of the rock. Calcite binds DNA with a high affinity, due to the strong chelating affinity of calcium ions for the phosphate backbone of the DNA molecule. Nevertheless, DNA extractions from rock and water samples gave positive results, as we recovered DNA prone to PCR amplification. Further analyses will be done on these DNA, namely sequencing of the $16 \mathrm{~S}$ rRNA genes, to get a picture of the micoorganisms inhabiting the LSBB galleries. 

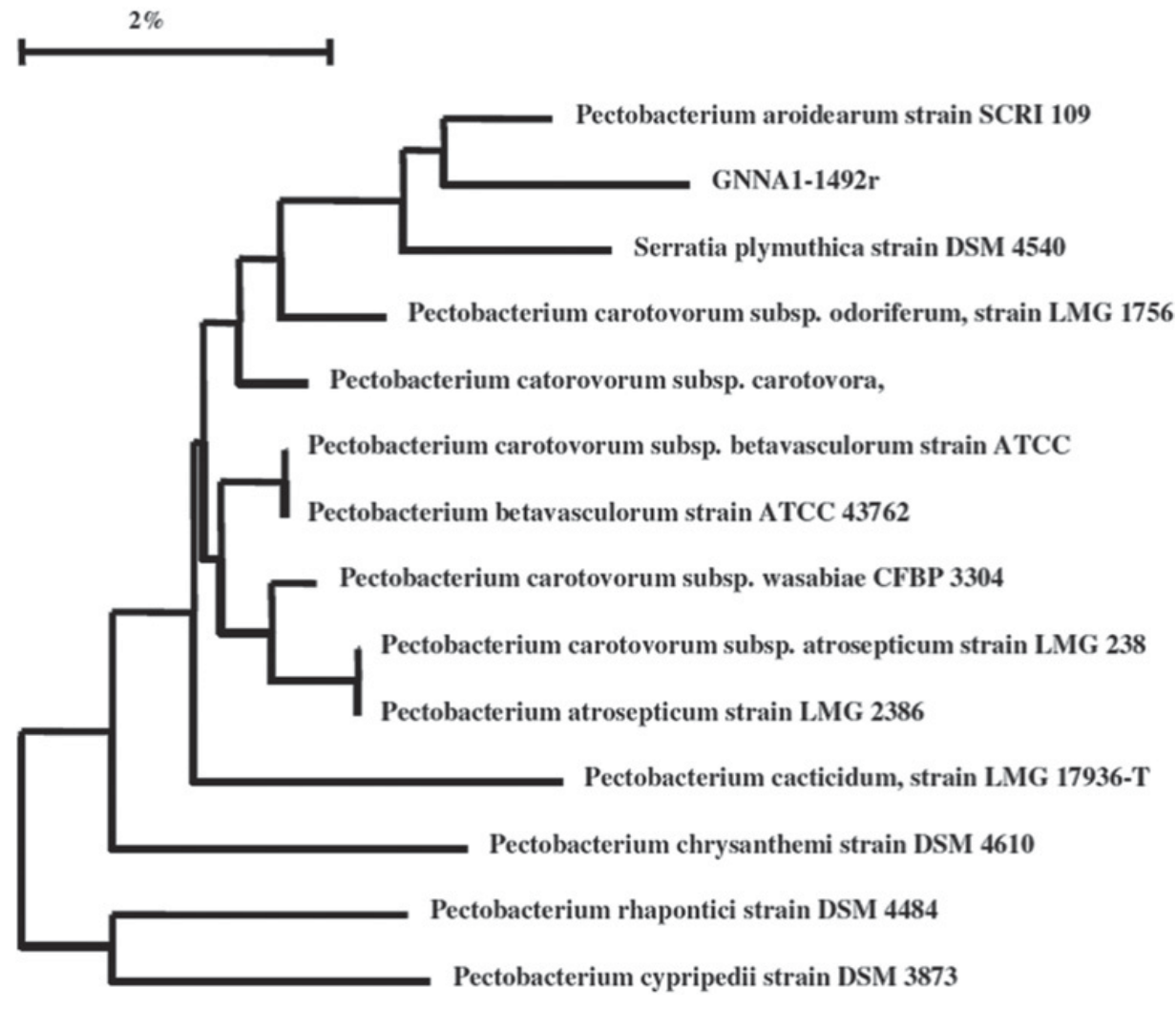

Figure 2. Neighbour-joining phylogenetic tree of 16S rRNA gene sequence showing the relationships between strain GNNA1 and related type strains amongst Proteobacteriales.

Table 1. Functional diversity of microorganisms recovered from the LSBB. + means presence and isolation of the microorganisms, $+^{*}$ means presence but not isolation (work in progress) and $\emptyset$ means absence.

\begin{tabular}{|l|c|c|c|c|c|}
\hline $\begin{array}{l}\text { Sample } \\
\text { location }\end{array}$ & $\begin{array}{l}\text { Fermentative or } \\
\text { respiratory }\end{array}$ & $\begin{array}{l}\text { Nitrate- } \\
\text { reducing }\end{array}$ & $\begin{array}{l}\text { Sulfate- } \\
\text { reducing }\end{array}$ & $\begin{array}{l}\text { FeIII- } \\
\text { reducing }\end{array}$ & $\begin{array}{l}\text { Methano- } \\
\text { genic }\end{array}$ \\
\hline $\begin{array}{l}\text { Anti-Blast } \\
\text { Gallery Solid }\end{array}$ & + & + & $\emptyset$ & $+^{*}$ & $+^{*}$ \\
\hline $\begin{array}{l}\text { Anti-Blast } \\
\text { Gallery Liquid }\end{array}$ & + & $\varnothing$ & $\varnothing$ & $\varnothing$ & $\emptyset$ \\
\hline $\begin{array}{l}\text { Main Gallery } \\
\text { Liquid }\end{array}$ & + & $\varnothing$ & $\varnothing$ & $\varnothing$ & $+^{*}$ \\
\hline $\begin{array}{l}\text { Safety Gallery } \\
\text { Solid }\end{array}$ & + & $\varnothing$ & $\varnothing$ & $\varnothing$ & $\emptyset$ \\
\hline
\end{tabular}

\subsection{Isolation of microorganisms}

Several aerobic microorganisms were isolated from solid and liquid samples. Functional diversity of microorganisms is given Table 1 .

Microorganisms isolated belonged to genera like Bacillus, Micrococcus, Acidovorax, Herbaspirillum and Stenotrophomonas. They were closely affiliated (more than 99\%) to known and described species. We found in nitrate-reducing conditions a strain, GNNA1, whose affiliation is not sure, closely related to Pectobacterium aroidearum. We built a 
phylogenetic tree with 1000 bases (Fig. 2), showing that it could be a new species within the Pectobacterium genus. New sequencing of the 16S rRNA gene will be performed, to get the entire gene sequence and decipher whether it is a new species.

The Fungi isolated in the anti Blast gallery belongs to the Coniophora puteana species, a frequently described wood-degrader.

\section{Conclusion and perspectives}

First results show that the LSBB galleries are inhabited by a low diversity of culturable microorganisms with a strong influence of anthropogenic activities. Some results are clearly not predictable by classical thermodynamics, for example the presence of Iron-reducing microorganisms and the presence of methanogenic Archaea (for the moment, only detected by their methane production). Further studies including molecular ecology (e.g. highthroughput sequencing of the bulk DNA extracted from the samples, contouring the "Great Plate Count Paradox" [7]) will reveal if the species we isolated are actually representative of the LSBB microflora.

\section{References}

[1] E.G. Roussel, M.A. Bonavita, J. Querellou, B.A. Crag, G. Webster, D. Prieur, R.J. Parkes, Sci. 320 (2008).

[2] A.J. Phillips, A.B. Cunningham, R. Gerlach, R. Hiebert, C. Hwang, B.P. Lomans, J. Westrich, C. Mantilla, J. Kirksey, R. Esposito, L. Spangler, Environ. Sci. Technol. 50 (2016).

[3] B.L Maidak, J.R Cole, C.T. Jr. Parker, G.M. Garrity, N. Larsen, N. Li, T.G. Lilburn, M.J. McCaughey, G.J. Olsen, R. Overbeek, S. Pramanik, T.M. Schmidt, J.M. Tiedje, \& C.R. Woese, Nucl. Acids Res. 27 (1999).

[4] W.G. Weisburg, S.M. Barns, D.A. Pelletier, \& D.J. Lane, J. Bacteriol 173 (1991).

[5] J. Felsenstein, Evol. 39 (1985).

[6] K. Tamura, G. Stecher, D. Peterson, A. Filipski, S. Kumar, Mol Biol Evol. 30 (2013).

[7] R.I. Amann, W. Ludwig, K.H. Schleifer Microbiol Rev. 59 (1995). 